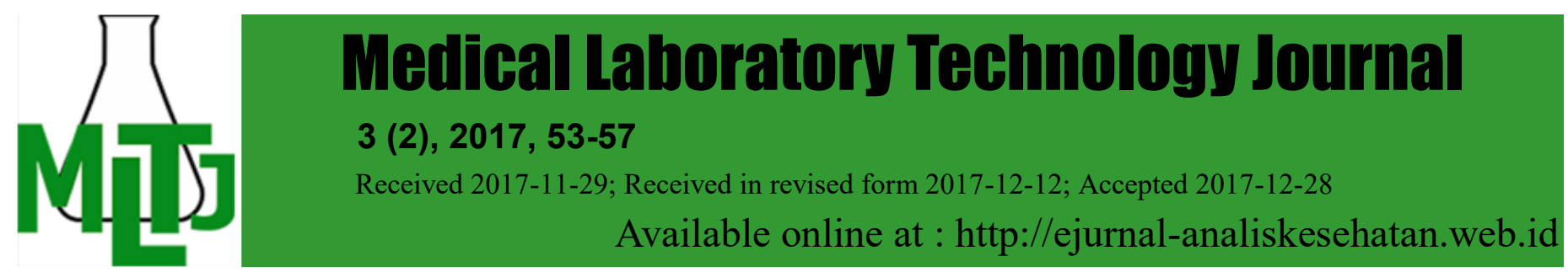

\title{
LOGAM MERKURI PADA MASKER PEMUTIH WAJAH DI PASAR MARTAPURA
}

\author{
Dinna Rakhmina, Lisa, Jasmadi Joko Kartiko
}

\author{
Jurusan Analis Kesehatan Poltekkes Kemenkes Banjarmasin \\ JI Mistar Cokrokusumo 4a Banjarbaru \\ e-mail: dinnapoltekesbjm@gmail.com
}

\begin{abstract}
Currently, many brands and types of skin whitening cosmetics can be found on the market. Not all products are safe for consumers. Illegal or non-licensed cosmetics from BPOM are suspect because unlisted cosmetics tend to contain harmful chemicals such as mercury $(\mathrm{Hg})$. Mercury $(\mathrm{Hg})$ was including harmful heavy metals. The use of mercury has been banned since 1998 through PERMENKES RI No. 445 of 1998, where mercury in small concentrations can be toxic. Negative effects of mercury such as allergies, skin irritation and permanent damage to the nervous system, kidney, brain and disrupt the development of the fetus, especially when used in high doses. The aim of this study was to know whether there is mercury content on bleach mask that sold in Martapura market in March 2017. This study used a descriptive method and the sample was taken by purposive sampling technique. There were 10 samples of face bleach mask that cost around Rp5.000,00 - Rp20.000,00. Based on the results of 10 samples taken at Martapura market, 3 samples contained mercury of face bleach mask. The conclusion of this study is that mercury still used as bleach on the facial in the Martapura market. Therefore, BPOM needs more supervision and intensive counseling about the risk of bleaching cosmetics containing mercury, so the consumer can be careful in choosing cosmetics.
\end{abstract}

Keywords: mercury; cosmetic; face bleaching mask

Abstrak: Saat ini banyak berbagai merek dan jenis kosmetik pemutih kulit dapat kita jumpai di pasaran. Tidak semua produk tersebut aman bagi konsumen. Kosmetik ilegal atau yang tidak memiliki nomor ijin dari BPOM inilah yang patut dicurigai karena kosmetik yang tidak terdaftar cenderung mengandung bahan-bahan kimia berbahaya seperti merkuri $(\mathrm{Hg})$. Merkuri $(\mathrm{Hg}) /$ air raksa termasuk logam berat berbahaya. Penggunaan merkuri telah dilarang sejak tahun 1998 melalui PERMENKES RI No. 445 Tahun 1998, dimana merkuri dalam konsentrasi kecil dapat bersifat racun. Efek negatif dari merkuri seperti timbulnya bintik-bintik hitam pada kulit, alergi, iritasi bahkan bisa menyebabkan kerusakan permanen pada susunan syaraf, ginjal, maupun otak serta mengganggu perkembangan janin terutama bila digunakan dalam dosis tinggi. Tujuan penelitian ini untuk mengetahui apakah ada kandungan merkuri pada masker pemutih yang dijual di pasar Martapura Maret 2017. Metode dalam penelitian ini menggunakan metode deskriptif dan sampel diambil dengan cara teknik purposive sampling. Populasi dalam penelitian ini adalah masker pemutih wajah yang beredar di Pasar Martapura. Sampel yang diambil sebanyak 10 sampel pada masker pemutih wajah yang harganya berkisar Rp5.000,00 Rp20.000,00. Dari 10 sampel masker wajah yang diuji pada penelitian ini yaitu 3 sampel atau $30 \%$ masker pemutih wajah mengandung merkuri. Dari hasil penelitian ini didapatkan kesimpulan bahwa merkuri masih digunakan sebagai bahan pemutih pada masker pemutih wajah yang beredar di Pasar Martapura. Oleh karena itu, diharapkan perlu pengawasan lebih ketat lagi serta peningkatan penyuluhan oleh instansi terkait tentang pentingnya bahaya kosmetik pemutih yang mengandung merkuri, sehingga masyarakat bisa teliti dalam memilih kosmetik.

Kata kunci: merkuri; kosmetik; masker pemutih wajah 
Medical Laboratory Technology Journal

\section{PENDAHULUAN}

Saat ini, banyak kaum wanita yang menggunakan berbagai macam sediaan kosmetika baik yang berfungsi untuk merawat awa kulit maupun untuk tata rias. Banyak macam kosmetika yang mempunyai daya tarik tersendiri bagi wanita. Para pembuat kosmetika ini mencoba untuk membuat suatu karya yang memang dibutuhkan oleh seorang wanita untuk tampil secantik mungkin dalam waktu sesingkat mungkin (Fauzi, A.R. dan Nurmalina, 2012).

Menurut Badan Pengawas Obat dan Makanan atau BPOM, (2015), kosmetika merupakan bahan atau sediaan yang dimaksudkan untuk digunakan pada bagian luar tubuh manusia (epidermis, rambut, kuku, bibir, dan organ genital bagian luar) atau gigi dan membran mukosa mulut, terutama untuk membersihkan, mewangikan, mengubah penampilan, dan/atau memperbaiki bau badan atau melindungi dan memelihara tubuh pada kondisi baik. Kosmetika lazimnya untuk mempercantik dan menyempurnakan penampilan seseorang. Begitu banyak jenis kosmetika yang dapat dijumpai salah satunya kosmetika yang dapat mengubah warna kulit yaitu produk kosmetik pemutih kulit. Sebagai konsumen kita harus berhati-hati dalam memilih produk kosmetik pemutih, karena tidak semua produk pemutih yang beredar di masyarakat aman untuk dipakai, seperti misalnya produk-produk yang mengandung bahan berbahaya seperti merkuri.

Merkuri $(\mathrm{Hg})$ dimanfaatkan secara ilegal dalam kosmetik sebagai bahan pemutih atau pencerah kulit karena kemampuannya dalam menghambat pembentukan melanin pada permukaan kulit. Merkuri mampu membuat kulit putih mulus dalam waktu yang relatif singkat, akan tetapi zat ini memberikan efek negatif bagi kesehatan karena dapat terakumulasi dalam tubuh. Hal ini dikarenakan merkuri yang masuk dalam tubuh manusia tidak mudah diekskresi. Unsur ini dapat terakumulasi dalam tubuh manusia terutama pada organ ginjal, hati dan otak (Asih, 2005; Widowati, W., Sastino, A. dan Jusuf, 2008). Paparan dalam jangka waktu yang lama dapat menyebabkan gangguan dan kerusakan organ-organ tersebut (Erasiska, Bali, \& Hanifah, 2015). Ada beberapa ciri kosmetik mengandung merkuri, antara lain yaitu: (1) krim terasa lengket, (2) krim terlihat kasar atau tidak menyatu, (3) Warna umumnya mencolok karena tidak menggunakan pewarna kosmetik dan menggunakan pewarna tekstil, (4) pemakaian awal menyebabkan iritasi, namun setelah itu menyebabkan ketergantungan, (5) jika pemakaian dihentikan akan timbul rasa gatal dan tidak nyaman (Erasiska et al., 2015; Sari, S, Noverda, \& Pratiwi, 2017).

Toksisitas akut dalam bentuk merkuri anorganik yaitu $\mathrm{HgCl}_{2}$ atau garam merkuri yang larut bisa menyebabkan kerusakan membrane alat pencernaan, eksanterma pada kulit, dekomposisi eritrosit, serta menurunkan tekanan darah. Toksisitas kronis meliputi gejala gangguan sistem syaraf, antara lain berupa tremor, anemia, albuminuria, dan gejala lain berupa kerusakan ginjal serta kerusakan mukosa usus. Toksisitas merkuri organik, seperti alkil merkuri atau metil merkuri memiliki sifat toksik yang lebih luas dibandingkan merkuri anorganik, karena mengakibatkan disfungsi blood-brain barrier, merusak permeabilitas membran, menghambat beberapa enzim, menghambat sintesis protein, dan menghambat penggunaan substrat protein (Rohaya, Ibrahim, \& Jamaluddin, 2017; Widowati, W., Sastino, A. dan Jusuf, 2008).

Pada pemeriksaan yang digelar Badan Pengawas Obat dan Makanan (BPOM) selama semester I tahun 2016 ditemukan 43 jenis kosmetika mengandung bahan berbahaya yang terdiri dari rias mata, rias wajah, perawatan kulit, sediaan mandi dan sediaan kuku. Bahan berbahaya yang teridentifikasi dalam produk kosmetika tersebut seperti merkuri, hidrokinon, dan lain-lain. Bahan-bahan berbahaya tersebut dilarang untuk digunakan dalam pembuatan kosmetika berdasarkan Peraturan Kepala BPOM RI No. 18 Tahun 2015 tentang Persyaratan Teknis Bahan Kosmetika.

Berdasarkan penelitian yang dilakukan di beberapa daerah, masih banyak beredar kosmetik yang mengandung merkuri. Diantaranya pada lotion, krim pemutih wajah, krim pagi dan malam (Armin, F., Zulharmita., Firda, 2013; Nurhayati, 2013; Parengkuan, K., Fatimawali dan Citraningtyas, 2013; Porong, 2013; Puspitasyari, P., Khristiani, E.R., Sekarwati, 2016). 
Hasil survei di pasar Martapura, Uji KI 0,5 N

menunjukkan bahwa banyak dijual berbagai Negatif (-) : Tidak terbentuk endapan merah macam merek masker pemutih wajah dan be- jingga

berapa diantaranya ditemukan adanya mask- Positif $(+)$ : Terbentuk endapan merah jingga

er pemutih wajah yang dijual tanpa ada nomor registrasi BPOM, hal ini dikhawatirkan produk pemutih tersebut kemungkinan mengandung bahan berbahaya seperti merkuri. Penelitian ini bertujuan untuk mengetahui apakah ada kandungan merkuri pada masker pemutih yang dijual di pasar Martapura Maret 2017.

\section{BAHAN DAN METODE}

Penelitian ini merupakan penelitian yang bersifat deskriptif dengan populasinya adalah masker pemutih wajah yang beredar di pasar Martapura. Jumlah sampel yang diperiksa sebanyak 10 sampel masker pemutih wajah yang harganya $\leq \mathrm{Rp} 20.000,00$. Penentuan sampel berdasarkan purposive sampling. Penelitian dilakukan pada sampel menggunakan uji amalgam dan uji KI 0,5 N pada bulan Maret 2017 di Laboratorium Kimia Dasar Jurusan Analis Kesehatan Politeknik Kesehatan Banjarmasin.

\section{HASIL DAN PEMBAHASAN}

Tabel 1. Hasil uji kualitatif merkuri pada masker pemutih wajah menggunakan uji amalgam dan uji KI 0,5 N

\begin{tabular}{|c|c|c|c|c|c|}
\hline \multirow[t]{2}{*}{ No. } & \multirow{2}{*}{$\begin{array}{l}\text { Kode } \\
\text { Sampel }\end{array}$} & \multirow{2}{*}{$\begin{array}{c}\text { Harga } \\
(\mathrm{Rp})\end{array}$} & \multirow[t]{2}{*}{ Nomor BPOM } & \multicolumn{2}{|c|}{ Hasil } \\
\hline & & & & Ujii Amalgam & Uji KI 0,5N \\
\hline 1 & Sampel A & 5000 & Tidak Terdaftar & Positif (+) & Positif (+) \\
\hline 2 & Sampel B & 10.000 & NA11160200307 & Negatif (-) & Negatif (-) \\
\hline 3 & Sampel C & 13.000 & NA18130200097 & Positif (+) & Positif (+) \\
\hline 4 & Sampel D & 5000 & Tidak Terdaftar & Rositif (+) & Rositif (+) \\
\hline 5 & Sampel E & 10.000 & $\begin{array}{l}\text { PencemaranNA } \\
140200163\end{array}$ & Negatif (-) & Negatif (-) \\
\hline 6 & Sampel F & 10.000 & NA18150200323 & Negatif (-) & Negatif (-) \\
\hline 7 & Sampel G & 7.500 & NA18140200543 & Negatif (-) & Negatif (-) \\
\hline 8 & Sampel H & 7.500 & NA18120200230 & Negatif (-) & Negatif (-) \\
\hline 9 & Sampel I & 18.000 & NA11140200167 & Negatif (-) & Negatif (-) \\
\hline 10 & Sampel J & 14.000 & Tidak Jerdaftar & Negatif (-) & Negatif (-) \\
\hline
\end{tabular}

Keterangan Hasil:

Uji Amalgam

Negatif $(-) \quad$ : Tidak terbentuk warna perak pada batang tembaga

Positif $(+)$ : Terbentuk warna perak pada batang tembaga

Pada penelitian ini didapatkan hasil sebanyak 3 sampel (30\%) masker pemutih wajah yang beredar mengandung merkuri. Sampel tersebut yaitu sampel A, sampel C dan sampel D.

Sampel dalam penelitian ini sebanyak 10 sampel, 3 dari 10 sampel tidak memiliki nomor registrasi BPOM. Sampel tersebut tidak termasuk dalam daftar produk kosmetik yang sudah ditarik oleh BPOM dari pasaran sehingga masih banyak ditemukan pada pedagang kosmetik di Pasar Martapura.

Pada penelitian ini pemeriksaan merkuri pada masker pemutih wajah secara kualitatif dilakukan dengan dua metode dan dua kali pengulangan. Metode uji yang pertama yaitu uji amalgam pada batang tembaga dan metode uji kedua uji reaksi warna dengan KI $0,5 \mathrm{~N}$. Pada uji amalgam dilakukan pengamatan pada permukaan batang tembaga, dimana hasil positif menunjukkan permukaan batang tembaga dilapisi bercak abu-abu mengkilap dan membentuk endapan logam merkurium. Hal tersebut terjadi dari hasil reaksi (Svehla, 1990) :

$\mathrm{Cu}+\mathrm{Hg}_{2}{ }^{2+} \rightarrow \mathrm{Cu}^{2+}+2 \mathrm{Hg} \downarrow$

Dari hasil uji amalgam, sampel $A$, sampel

C dan sampel $D$ pada batang tembaga menunjukkan bercak abu-abu mengkilap seperti pada batang tembaga pada kontrol positif. Pada sampel yang positif, jika kawat tembaga didiamkan dalam sampel cukup lama, maka akan terbentuk endapan logam merkuri secara berlebih menyebabkan kawat tembaga akan ikut larut dalam larutan sampel tersebut. Dengan adanya asam sulfat dalam larutan yang merupakan hasil dari oksidasi dari belerang yang didapatkan pada saat pemanasan larutan uji maka tembaga yang ikut terlarut akan menyebabkan perubahan warna larutan sampel menjadi hijau tua sampai biru.

Pada uji $\mathrm{KI}$ 0,5 $\mathrm{N}$ dengan metode reaksi warna, sampel yang positif yaitu sampel $A$, sampel $C$ dan sampel $D$ yang mengandung logam berat merkuri akan membentuk endapan merah jingga seperti pada kontrol positif, hal ini dikarenakan terjadi reaksi (Svehla, 1990): $\mathrm{Hg}^{2+}+2 \mathrm{I}^{-} \rightarrow \mathrm{Hgl}_{2} \downarrow$ 
Pada sampel yang negatif, larutan sampel akan berwarna kuning dan tidak terjadi endapan hal ini sama seperti kontrol negatif. Hasil penelitian yang dilakukan secara kualitatif pada kesepuluh sampel masker pemutih wajah yang beredar di pasar Martapura didapatkan hasil positif mengandung merkuri pada tiga sampel masker pemutih wajah yang diperiksa yaitu sampel $A$, sampel $C$, dan sampel D.

Sampel yang terdeteksi merkuri adalah sampel yang beredar di masyarakat dan dijual bebas di pasaran. Hal ini seharusnya diperhatikan oleh pemerintah dalam mengedarkan berbagai produk-produk pemutih wajah, karena dua sampel positif yang mengandung merkuri yaitu sampel $A$ dan sampel $D$ sudah jelas tidak memiliki nomor registrasi BPOM dan masih beredar di masyarakat. Hal ini sejalan dengan penelitian yang dilakukan oleh Herliana pada penelitiannya terhadap krim pemutih wajah tanpa nomor registrasi yang dijual di Pasar Tamban Kabupaten Barito Kuala, pada 9 sampel yang diperiksa menunjukkan semua sampel positif.

Berbeda dengan sampel $\mathrm{C}$ yang memiliki nomor BPOM tetapi dari hasil uji menunjukkan positif merkuri, dalam hal ini kemungkinan sampel tersebut pada saat pengolahan atau pengemasan produk tidak sengaja tercemar logam merkuri. Berdasarkan Peraturan Kepala BPOM RI Nomor 17 Tahun 2014 tentang Persyaratan Cemaran Mikroba dan Logam Berat dalam Kosmetika, batas cemaran merkuri $(\mathrm{Hg})$ yaitu tidak lebih dari $1 \mathrm{mg} / \mathrm{kg}$ atau $1 \mathrm{mg} / \mathrm{L}$ (1 bpj). Sedangkan, pada penelitian ini hanya terbatas pada uji kualitatif sehingga tidak dapat diketahui apakah sampel yang positif memenuhi persyaratan batas cemaran merkuri atau tidak. Tetapi tidak menutup kemungkinan merkuri ditambahkan dengan sengaja dengan tujuan untuk menarik konsumen untuk mendapatkan kulit putih dalam waktu singkat. Oleh karena itu, sebagai konsumen tetaplah harus teliti dan meningkatkan kewaspadaan terhadap produk-produk pemutih yang beredar dipasaran.

Penelitian ini bersesuaian dengan beberapa penelitian terdahulu dimana pada lotion dan krim pemutih wajah yang beredar di wilayah Kalimantan Selatan masih ada yang mengandung merkuri (Parengkuan, 2013; Herliana, dkk., 2016; Sari, dkk., 2017). Masih banyaknya ditemukan merkuri pada masker pemutih wajah terutama pada kosmetik tanpa nomor registrasi kemungkinan disebabkan antara lain, banyaknya keinginan konsumen untuk mendapatkan kulit putih dengan cepat, produsen ingin mendapatkan keuntungan yang berlipat ganda, dan kurangnya pengawasan dari BPOM sehingga masker pemutih yang mengandung merkuri masih beredar luas di pasaran. Oleh karena itu, BPOM sebagai lembaga resmi untuk pengawasan obat dan makanan agar lebih intensif dalam melakukan pengawasan terhadap peredaran kosmetik yang dijual di pasar

\section{KESIMPULAN}

Berdasarkan hasil uji kualitatif merkuri pada masker pemutih wajah yang dijual di Pasar Martapura Maret 2017 dengan menggunakan metode uji amalgam dan uji KI 0,5 $\mathrm{N}$ dapat disimpulkan bahwa ada kandungan merkuri pada masker pemutih wajah yang dijual di pasar Martapura dimana 3 sampel atau $30 \%$ sampel yang mengandung merkuri dan 7 sampel atau $70 \%$ sampel yang tidak mengandung merkuri.

\section{SARAN}

Bagi peneliti selanjutnya diharapkan agar dapat meneliti tentang gambaran kandungan merkuri pada masker pemutih wajah yang dijual dengan harga lebih mahal dibandingkan masker pemutih wajah yang dijual dengan harga murah.

\section{DAFTAR PUSTAKA}

Armin, F., Zulharmita., Firda, D. R. (2013). Identifikasi Dan Penetapan Kadar Merkuru $(\mathrm{Hg})$ Dalam Krim Pemutih Kosmetika Herbal Menggunakan Spektofotometri Serapan Atom (SSA). Jurnal Sains Dan Teknologi Farmasi, Vol. 18(No.1), 28-34.

Asih, S. . (2005). Dampak Penggunaan Kosmetik Pemutih terhadap Kesehatan Kulit Ibu-ibu di RW II Desa Limpung. Universitas Negeri Semarang.

BPOM. Peraturan Kepala Badan Pengawas Obat dan Makanan Republik Indonesia Nomor 18 tentang Persyaratan Teknis Bahan Kosmetika. (2015). 
Erasiska, Bali, S., \& Hanifah, T. A. (2015). Analisis Kandungan Logam Timbal, Kadmium Dan Merkuri Dalam Produk Krim Pemutih Wajah. JOM FMIPA, 2(1).

Fauzi, A.R. dan Nurmalina, R. (2012). Merawat Kulit dan Wajah. Jakarta: Gramedia.

Nurhayati. (2013). Analisis Merkuri Dalam Sediaan Krim A Dan Krim B (Tidak Terdaftar) Yang Dibeli Melalui Internet (Secara Online). Jurnal IImiah Mahasiswa Universitas Surabaya, 2(2).

Parengkuan, K., Fatimawali dan Citraningtyas, G. (2013). Analisis Kandungan Merkuri pada Krim Pemutih yang Beredar Di Kota Manado. Jurnal IImiah FarmasiUNSRAT, 2(1).

Porong, V. (2013). Analisis Kandungan Merkuri pada Kosmetik Pemutih Wajah yang dijual Pedagang Kaki Lima di Pasar 45 Kota Manado. Jurnal Universitas SAM Ratulangi.

Puspitasyari, P., Khristiani, E.R., Sekarwati, N. (2016). Analisis Kandungan Merkuri (Hg) Pada Krim Pagi Dan Krim Malam di Klinik Kecantikan Yogyakarta. MIKKI, 4(1).

Rohaya, U., Ibrahim, N., \& Jamaluddin. (2017). Analisis Kandungan Merkuri (Hg) Pada Krim Pemutih Wajah Tidak Terdaftar Yang Beredar Di Pasar Inpres Kota Palu. GALENIKA Journal of Pharmacy, 3(1), 77-83.

Sari, A. K., Sari, A. K., S, M. M. A., Noverda, A., \& Pratiwi, M. E. (2017). Analisis Kualitatif Merkuri Pada Lotion Peutih Yang Dijual Di Online Shop Daerah Kota Banjarmasin. Jurnal IImiah Ibnu Sina, 2(1), 13-19.

Widowati, W., Sastino, A. dan Jusuf, R. (2008). Efek Toksik Logam Pencegahan dan Penanggulangan Pencemaran. Yogyakarta: ANDI. 